Article

\title{
Performance Evaluation of CRW Reef-Scale and Broad-Scale SST-Based Coral Monitoring Products in Fringing Reef Systems of Tobago
}

\author{
Shaazia S. Mohammed ${ }^{1, *}$, Scott F. Heron ${ }^{2,3,4}$, Rajindra Mahabir ${ }^{5}$ and Ricardo M. Clarke ${ }^{1}$ \\ Received: 16 September 2015; Accepted: 15 December 2015; Published: 24 December 2015 \\ Academic Editors: Stuart Phinn, Chris Roelfsema, Xiaofeng Li and Prasad Thenkabail \\ 1 Environmental Physics Laboratory, Department of Physics, Faculty of Science and Technology, \\ The University of the West Indies, St. Augustine, Trinidad \& Tobago; ricardo.clarke@sta.uwi.edu \\ 2 Coral Reef Watch, U.S. National Oceanic and Atmospheric Administration, College Park, MD 20740, USA; \\ scott.heron@noaa.gov \\ 3 Global Science and Technology, Inc., Greenbelt, MD 20770, USA \\ 4 Marine Geophysical Laboratory, Physics Department, College of Science, Technology and Engineering, \\ James Cook University, Townsville 4811, Australia \\ 5 Department of Life Sciences, Faculty of Science and Technology, The University of the West Indies, \\ St. Augustine Circular Road, Trinidad and Tobago; rajendra.mahabir@sta.uwi.edu \\ * Correspondence: shaaziamohammed@hotmail.com; Tel.: +1-868-662-2002 (ext. 3844); Fax: +1-868-645-3830
}

\begin{abstract}
Satellite-derived sea surface temperature (SST) is used to monitor coral bleaching through the National Oceanic and Atmospheric Administration's Coral Reef Watch (CRW) Decision Support System (DSS). Since 2000, a broad-scale $50 \mathrm{~km} \mathrm{SST} \mathrm{was} \mathrm{used} \mathrm{to} \mathrm{monitor} \mathrm{thermal} \mathrm{stress} \mathrm{for} \mathrm{coral}$ reefs globally. However, some discrepancies were noted when applied to small-scale fringing coral reefs. To address this, CRW created a new DSS, specifically targeted at or near reef scales. Here, we evaluated the new reef-scale ( $5 \mathrm{~km}$ resolution) products using in situ temperature data and coral bleaching surveys which were also compared with the heritage broad-scale $(50 \mathrm{~km})$ for three reefs (Buccoo Reef, Culloden and Speyside) of the southern Caribbean island of Tobago. Seasonal and annual biases indicated the new $5 \mathrm{~km}$ SST generally represents the conditions at these reefs more accurately and more consistently than the $50 \mathrm{~km}$ SST. Consistency between satellite and in situ temperature data influences the performance of anomaly-based predictions of bleaching: the $5 \mathrm{~km}$ DHW product showed better consistency with bleaching observations than the $50 \mathrm{~km}$ product. These results are the first to demonstrate the improvement of the $5 \mathrm{~km}$ products over the $50 \mathrm{~km}$ predecessors and support their use in monitoring thermal stress of reefs in the southern Caribbean.
\end{abstract}

Keywords: coral reefs; coral bleaching; sea surface temperature (SST); satellite remote sensing; NOAA Coral Reef Watch; Tobago; Caribbean

\section{Introduction}

Over the past decades coral reefs have been exposed to thermal stress resulting in the onset of several temperature-induced coral bleaching events [1,2]. These events have threatened to reduce fishery population [3,4], while simultaneously affecting the economic benefits of tourism that supports many coastal communities [5,6]. Effective management of coral reefs and associated ecosystem services has been aided in recent decades by satellite remote sensing monitoring that provides near real-time sea temperature (SST) data and customized products [7-13]. Mass coral bleaching has been related to anomalously high sea temperatures and has resulted in increased mortality of corals globally $[7,14]$. 
The U.S. National Oceanic and Atmospheric Administration (NOAA) Coral Reef Watch (CRW) program delivers global thermal stress products for coral reef management via its web-based Decision Support System (DSS; coralreefwatch.noaa.gov) [7]. Available since 2000, the heritage $50 \mathrm{~km}$ products are underpinned by satellite-derived temperatures calibrated using open-ocean in situ measurements from $1 \mathrm{~m}$ depth $[15,16]$. Surface temperature variation during daylight hours can result in surface temperature not necessarily representing the water temperature at the depths in which corals live [17]. To reduce errors caused by diurnal variation, CRW has used only nighttime SST [7]. The twice-weekly $50 \mathrm{~km}$ NOAA CRW monitoring products have successfully detected thermal stress associated with coral bleaching [15,18-20] and have been used to study the magnitude and onset of large scale bleaching events across broad spatial scales [21,22]. However, thermal stress in reefs at smaller scales, located near the coast, might be inaccurate due to localized effects [20,23]. This has sometimes been attributed to the conservative landmask of the $50 \mathrm{~km}$ products that results in the nearest SST-containing pixels being up to $50 \mathrm{~km}$ from reefs [23]. This leads to the potential for higher uncertainty of the $50 \mathrm{~km} \mathrm{SST}$ products to represent thermal stress occurring in fringing coral reef systems.

To address this, CRW developed a new reef-scale DSS using $5 \mathrm{~km}$ global daily blended SST derived from geostationary and polar orbiting satellites [23-25]. Along with the increased number of data inputs, the new SST product incorporates enhanced cloud screening and gap-filling algorithms resulting in higher quality SST values [25]. The CRW $5 \mathrm{~km}$ DSS consists of SST Anomaly, Coral Bleaching HotSpot, Degree Heating Week and Bleaching Alert Area products, consistent with the heritage $50 \mathrm{~km}$ products [23]. Initial application of the $5 \mathrm{~km}$ DSS identified notable differences in the distribution and intensity of thermal stress, compared with the $50 \mathrm{~km}$ products, and recognized the need to undertake quantitative comparisons of the performance of the $5 \mathrm{~km}$ and $50 \mathrm{~km}$ products [23].

Here, we evaluate the new $5 \mathrm{~km}$ with in situ temperature (IST) and bleaching observations as well as compare with the heritage $50 \mathrm{~km}$ products to evaluate their use to monitor thermal stress in fringing coral reefs on small island coastal reef systems. Our case study is for three fringing reefs off Tobago, a southern Caribbean island. Bleaching surveys conducted in 2013 and 2014 were used to evaluate the new $5 \mathrm{~km}$ and heritage $50 \mathrm{~km}$ thermal stress products.

\section{Study Area}

In the southern Caribbean Sea, the island of Tobago contains fringing shallow water coral reefs along the edges of its coastline, most of which slope to the sea bed at $20 \mathrm{~m}$ [26]. The island is located at approximately $11^{\circ} 11^{\prime} \mathrm{N}, 60^{\circ} 39^{\prime} \mathrm{W}$ and is in close proximity to the South American continent (Figure 1). These reefs are exposed to extreme environmental conditions related to movement of the Inter-Tropical Convergence Zone (ITCZ) [27]; upwelling along the north coast of Venezuela [27]; and run-off from the Orinoco River delta, $\sim 250 \mathrm{~km}$ south of Tobago [28]. Tobago's fringing reefs are typically exposed to temperatures in the range $25-29{ }^{\circ} \mathrm{C}$ and annually experience sediment loading [29]. Rainfall patterns in the region drive two distinct seasons for these reefs: a dry season (January to May); and a wet season (June to December) [30]. Tobago's reefs are considered to be high to very high risk from localized anthropogenic factors [31], such as coastal development, tourism activities and marine-based pollution, all of which stem from poor management practices and lack of enforcement and monitoring [5].

In recent years, these coral reefs have been exposed to additional impacts of temperature-induced coral bleaching events $[21,32,33]$. Mass bleaching events occurred across the Caribbean in 2005 and 2010, including Tobago [31,32]. Observations of coral mortality highlighted a staggering 75\% mortality of corals in Tobago after this 2005 event [32]. The recent exposure of Tobago's small-scale fringing reefs to coral bleaching makes it a strong candidate to examine the performance of satellite SST-based datasets, including the new CRW daily global $5 \mathrm{~km}$ DSS. Our study areas were Buccoo Reef, Culloden and Speyside (Figure 1), three of the largest fringing reef extents in Tobago. Buccoo Reef $\left(11^{\circ} 11^{\prime} \mathrm{N}, 60^{\circ} 49^{\prime} \mathrm{W}\right)$ and Culloden $\left(11^{\circ} 14^{\prime} \mathrm{N}, 60^{\circ} 45^{\prime} \mathrm{W}\right)$ are 
located along the southwestern section of Tobago on a foundation of coralline limestone. Ocean currents pass through the channel between Trinidad and Tobago and follow a northward direction along Tobago's Caribbean and Atlantic coastlines. Buccoo Reef extends to $3 \mathrm{~km}$ offshore and consists of a shallow lagoon ranging in depths from 2-6 m containing several patch reefs and reef flats, with corals also present on the reef slope to $20 \mathrm{~m}$ depth [26]. Shallow reefs are sheltered from the northeast trade winds, while slope reefs are exposed to wind and wave action. Buccoo corals are impacted by tourism activities (e.g., reef walking) and coastal development (e.g., nutrient enrichment). Culloden reefs are fringing reefs at depths $5-30 \mathrm{~m}$ within $0.5 \mathrm{~km}$ of the coast with no lagoon. Shallow reefs are within a west-facing semi-enclosed bay, while deeper reefs are exposed to oceanic conditions. Speyside reef $\left(11^{\circ} 17^{\prime} \mathrm{N}, 60^{\circ} 30^{\prime} \mathrm{W}\right)$ is located on the northeastern end of Tobago, with fringing reefs established on igneous rock at depths of 5-30 $\mathrm{m}$ [32]. Speyside is exposed to the influence of warm bands of Orinoco freshwater in the wet season as well as the year-round influence of the northeast trade winds, which induce turbulent mixing in the water column. Currents in this area efficiently circulate the water resulting in a low residence time.

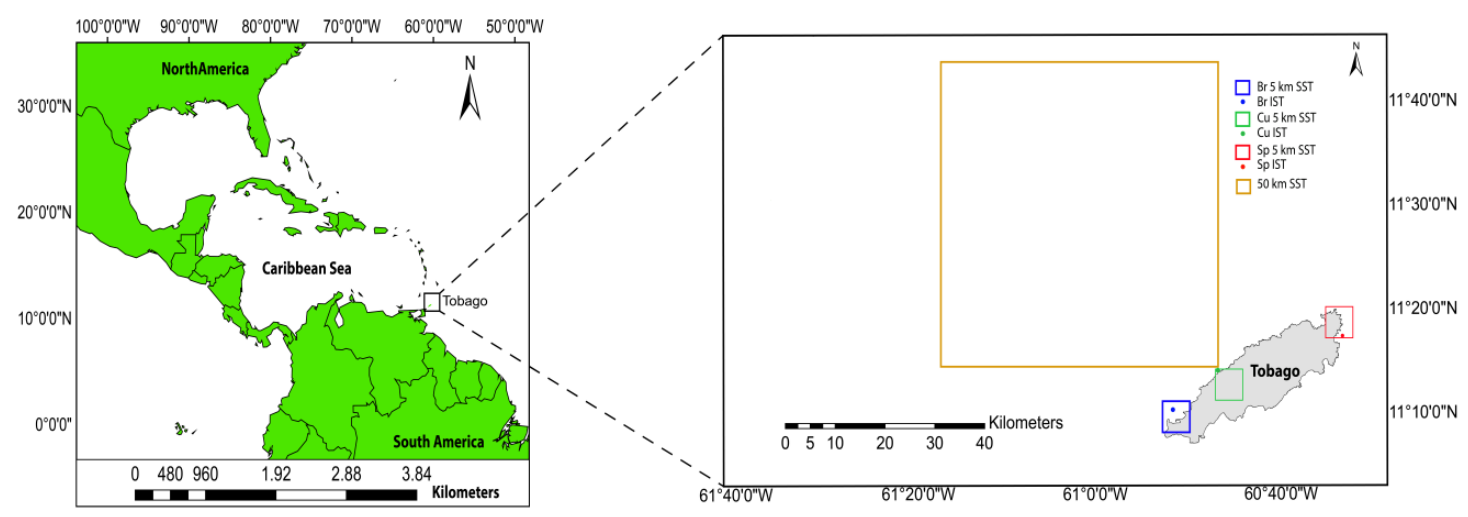

Figure 1. Locations of the three Tobago reefs and satellite pixels from which in situ temperature and sea surface temperature measurements, respectively, were analyzed. Blue, green and red represent Buccoo Reef (Br), Culloden $(\mathrm{Cu})$ and Speyside (Sp), respectively, here and in the following figures.

\section{Experimental Section}

\subsection{Satellite Data}

Production of the $50 \mathrm{~km}$ night-only, twice-weekly SST is described in [34] and summarized here. The $50 \mathrm{~km}$ (precisely $0.5^{\circ}$ ) SST is derived using nighttime retrievals from the Advanced Very High Resolution Radiometer (AVHRR) sensor onboard NOAA's primary Polar Orbiting Environmental Satellite (currently NOAA-19) [25,34]. This satellite completes 14 near-polar orbits daily providing coverage of almost all global locations once each day. The quality of the SST retrieval might be compromised where clouds are present or high local variability exists. To counter this, SST retrievals are sub-sampled from within broader scale $\left(\sim 0.5^{\circ}\right)$ target regions, selecting the warmest, high-quality SST values. Where insufficient high quality values exist, gaps are filled using distance-weighted averages of nearby high quality observations, up to $150 \mathrm{~km}$ from the gap location [34]. Finally, where no nearby observations are of high quality, the most recent SST from the gap pixel is persisted. This ensures a spatially replete SST product, which has been produced for nearly 20 years.

The more-recent NOAA/NESDIS Blended $5 \mathrm{~km}$ night-only daily SST product blends SST data from multiple geo-stationary and polar orbiting satellites [23]. Each $5 \mathrm{~km}$ (precisely $0.05^{\circ}$ ) SST pixel value is derived from as many as 50 SST observations per day [35]. In addition to increased frequency of observations, the use of latest algorithms for cloud screening, SST calculation and gap filling further increases the quality of the $5 \mathrm{~km}$ SST product compared with the $50 \mathrm{~km}$ SST product [25]. 


\subsection{In Situ Data}

In situ temperatures (IST) were extracted from ongoing monitoring programs for coral reefs in Tobago for the period 1 January 2014 to 31 December 2014. This period covers a full dry season (January to May) and a full wet season (June to December), the latter including the three-month period (August to October) during which bleaching has previously occurred [32,33]. Water temperature was monitored using U22-001 HOBO Water Temperature Pro v2 loggers (nominal accuracy $\pm 0.21{ }^{\circ} \mathrm{C}$ ) [36] and recorded at 15-min intervals. Loggers were deployed at $\sim 5 \mathrm{~m}$ depth for each of the three reefs (locations in Table 1), affixed to a metal stake driven into the sea floor. Prior to deployment temperature loggers were cross-verified by collectively exposing the loggers to the expected temperature range and were found to be consistent. Within the monitoring programs, loggers are collected for cleaning and retrieval of data twice each year. Data were downloaded using the USB Optic Base Station (BASE U-4) and extracted using the HOBOware PRO v.3.x software [36]. The Buccoo Reef logger was deployed on a patch reef that is exposed to oceanic waters via a channel between reef flats. The Culloden logger was deployed close to shore in the northern section of the semi-enclosed bay, therefore sheltered from oceanic influences. The Speyside logger was deployed off Goat Island in Speyside Bay, where depth rapidly drops to greater than $40 \mathrm{~m}$ around the island.

Table 1. Locations of sea surface temperature (SST) (satellite pixel center) and in situ temperature IST measurements for Tobago reefs.

\begin{tabular}{cccc}
\hline & Buccoo Reef & Culloden & Speyside \\
\hline \multirow{2}{*}{$50 \mathrm{~km} \mathrm{SST}$} & $11.5^{\circ} \mathrm{N}$ & $11.5^{\circ} \mathrm{N}$ & $11.5^{\circ} \mathrm{N}$ \\
& $61.0^{\circ} \mathrm{W}$ & $61.0^{\circ} \mathrm{W}$ & $61.0^{\circ} \mathrm{W}$ \\
\hline \multirow{2}{*}{$5 \mathrm{~km} \mathrm{SST}$} & $11.175^{\circ} \mathrm{N}$ & $11.225^{\circ} \mathrm{N}$ & $11.325^{\circ} \mathrm{N}$ \\
& $60.825^{\circ} \mathrm{W}$ & $60.725^{\circ} \mathrm{W}$ & $60.525^{\circ} \mathrm{W}$ \\
\hline \multirow{2}{*}{ IST at 5 m depth } & $11.18689^{\circ} \mathrm{N}$ & $11.24894^{\circ} \mathrm{N}$ & $11.30225^{\circ} \mathrm{N}$ \\
& $60.83178^{\circ} \mathrm{W}$ & $60.74867^{\circ} \mathrm{W}$ & $60.51944^{\circ} \mathrm{W}$ \\
\hline
\end{tabular}

\subsection{In Situ and Satellite Data Comparison}

SST time series for both $50 \mathrm{~km}$ and $5 \mathrm{~km}$ products were extracted from the water pixels containing $(5 \mathrm{~km})$ or nearest to $(50 \mathrm{~km})$ each of the IST stations in Tobago (Figure 1). Table 1 provides the locations of each pixel for which SST data were extracted for both satellite datasets. Note that the same $50 \mathrm{~km}$ pixel was identified for all three reefs, due to the conservative land mask applied in the $50 \mathrm{~km}$ SST [23]. Further, we observed that the pixel containing the Culloden deployment was predominantly over land. While the $5 \mathrm{~km}$ SST algorithm ensures only information from water retrievals contributes to the final value [23], the small coverage of water by this pixel suggests that values here may heavily incorporate data from surrounding locations through the gap-filling algorithm.

As the satellite SST products are derived using only nighttime retrievals, IST values recorded between 6:00 p.m. and 6:00 a.m. (local time) were extracted and averaged for comparison with SST. In the absence of turbulent mixing, diurnal warming can result in substantial variations in the vertical temperature profile [37]. Nighttime temperatures are consistent near the surface [37] and temperature anomaly is generally consistent from surface to depths of $\sim 100 \mathrm{~m}$ [38]. Average values for each 12-h nightly period were calculated for comparison with the night-only $5 \mathrm{~km}$ data produced each day. For comparison with the twice-weekly $50 \mathrm{~km} \mathrm{SST} \mathrm{data,} \mathrm{nighttime} \mathrm{IST} \mathrm{were} \mathrm{averaged} \mathrm{over}$ Saturday through Monday and, separately, Tuesday through Friday [34]. Collated pairs were then generated from satellite SST and IST datasets for each of the $5 \mathrm{~km}$ daily and $50 \mathrm{~km}$ twice-weekly satellite datasets. 
Comparison between each of the $50 \mathrm{~km}$ and $5 \mathrm{~km}$ SST datasets with IST was evaluated using the bias and root mean square error (RMSE) [39]:

$$
\begin{gathered}
\text { bias }=\frac{1}{N} \sum_{i=1}^{N} S S T_{i}-I S T_{i} \\
R M S E=\sqrt{\frac{1}{N} \sum_{i=1}^{N}\left(S S T_{i}-I S T_{i}\right)^{2}}
\end{gathered}
$$

where $S S T_{i}$ and $I S T_{i}$ are collated pairs (of total number $N$ ).

\subsection{Calculated Thermal Stress Variations Using $50 \mathrm{~km}$ and $5 \mathrm{~km}$ SST Datasets}

Coral bleaching thermal stress, at $50 \mathrm{~km}$ and $5 \mathrm{~km}$ resolution, is derived using each SST dataset with its corresponding (i.e., matching resolution) monthly climatologies (see [34,40] for information on the $50 \mathrm{~km}$ and $5 \mathrm{~km}$ climatologies, respectively). The first coral-specific metric, HotSpot (HS), is the positive anomaly above the location-specific warmest value in the monthly climatology, known as the Maximum of the Monthly Mean (MMM) SST climatology [34,40]. HS describes the current magnitude of thermal stress. CRW's Degree Heating Week (DHW) metric is the most widely adopted measurement for accumulated thermal stress on corals and provides the best prediction of bleaching stress [21]. It is derived by accumulating HotSpot values of $1^{\circ} \mathrm{C}$ or greater through a 12-week period. The DHW calculations are slightly different due to the different temporal resolutions of the $50 \mathrm{~km}$ and $5 \mathrm{~km}$ products $[23,34]$ :

$$
\begin{aligned}
& 50 \mathrm{~km} D H W=\frac{1}{2} \sum_{i=1}^{24}\left(H S_{i}, \text { if } H S_{i} \geqslant 1^{\circ} \mathrm{C}\right) \\
& 5 \mathrm{kmDHW}=\frac{1}{7} \sum_{i=1}^{84}\left(H S_{i}, \text { if } H S_{i} \geqslant 1^{\circ} \mathrm{C}\right)
\end{aligned}
$$

CRW provides Virtual Station time series graphics that summarize the $50 \mathrm{~km}$ thermal stress metrics for select reef locations as well as the underlying data [34]; Buccoo Reef is one of these locations. For the $5 \mathrm{~km}$ metrics, time series and data are provided for Regional Virtual Stations [41] based on metric values from pixels across each region. Here, we replicated the pixel-level time series graphics using the $5 \mathrm{~km}$ data to examine variations between the three reef sites.

\subsection{Bleaching Surveys}

Quantitative bleaching surveys were conducted during September in each of 2013 and 2014 at the three field sites off Tobago. The Reef Condition Monitoring Program (RECON) protocol [42] was chosen for the surveys based on its cost effectiveness and small requirement for human resources needed to carry out the survey. RECON was specifically developed to document reef status and the health of key reef organisms in the tropical western Atlantic. Following the RECON protocol, we surveyed 10 coral colonies at $5 \mathrm{~m}$ depth for each of the sites. Colonies were haphazardly selected in the vicinity of the deployed temperature loggers ( $5 \mathrm{~m}$ depth) and tagged (see in Table 2 for selected species). Initial surveys of the colonies chosen at each of the reef sites were conducted in July 2013 and subsequently monitored approximately every four months. This survey plan is part of an ongoing study undertaken by The University of the West Indies in Trinidad to measure the coral health within each of the three reef sites in Tobago. Estimates for percent bleached coral were recorded in September of 2013 and 2014, the climatologically warmest month and the usual peak of the bleaching season for Tobago [30]. It was also the only month in which coral bleaching was observed for these years. 
Table 2. Taxa and number of colonies surveyed (total 10) at the three reef sites in Tobago.

\begin{tabular}{ccc}
\hline Buccoo Reef & Culloden & Speyside \\
\hline Diploria strigosa (1) & Diplora strigosa (5) & Agaricia lamarcki (1) \\
Millepora alcicornis (1) & Montastraea cavernosa (2) & Diploria strigosa (3) \\
Montastraea annularis (6) & Montastraea faveolata (2) & Millepora alcicornis (1) \\
Porites porites (1) & Porites astreoides (1) & Millepora complanata (1) \\
Siderastrea radians (1) & & Porites porites (2) \\
& & Siderastrea radians (2) \\
\hline
\end{tabular}

\section{Results and Discussion}

\subsection{In Situ Water Temperature during 2014 for Buccoo Reef, Culloden and Speyside, Tobago}

In 2014, the annual average in situ temperature (IST) at all three monitoring stations was between 27 and $28^{\circ} \mathrm{C}$ (Figure 2), within the documented seasonal range of 25.5 and $29^{\circ} \mathrm{C}$ [29]. The temperature time series for the three monitoring stations indicated Speyside's corals experienced the highest annual mean temperature, $0.15{ }^{\circ} \mathrm{C}$ warmer than Buccoo Reef, which was, in turn, warmer than Culloden by $0.3^{\circ} \mathrm{C}$, but each with similar variability (Figure 3). During the three month bleaching season, August to October [29], Speyside was found to have had the highest seasonal average, $0.42{ }^{\circ} \mathrm{C}$ warmer than but with similar variability to Buccoo Reef. Culloden experienced the coolest bleaching season average, $0.75{ }^{\circ} \mathrm{C}$ lower than Speyside, but had the greatest variability among the three reef sites. The maximum bleaching season temperature experienced at Speyside during 2014 was $\mathrm{T}_{\operatorname{maxS}}=29.61{ }^{\circ} \mathrm{C}$, while Buccoo Reef's maximum temperature was $\mathrm{T}_{\operatorname{maxB}}=29.34{ }^{\circ} \mathrm{C}$. Consistent with the annual and bleaching season average temperatures, Culloden experienced the lowest maximum temperature of $\mathrm{T}_{\operatorname{maxC}}=29.23^{\circ} \mathrm{C}$. Distinctively higher temperatures at Speyside might be the result of warmer freshwater transported during the wet season from the Orinoco as observed by divers who frequent this reef site.

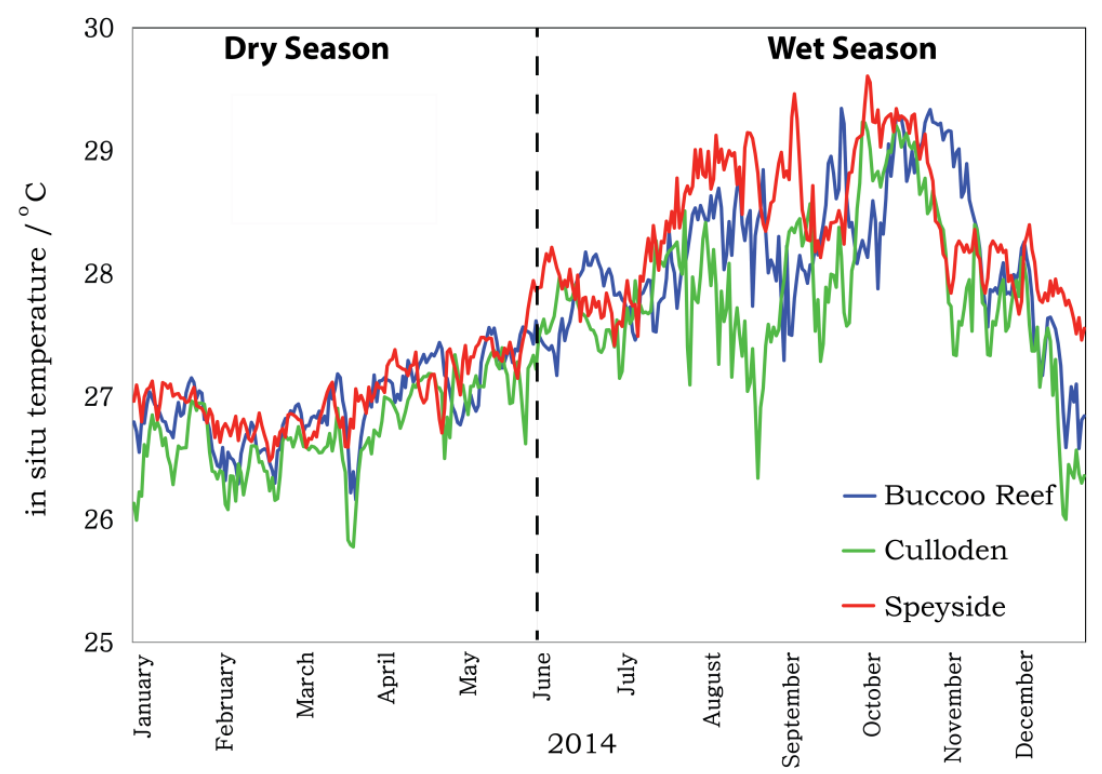

Figure 2. Time series of in situ temperatures for three coral reef monitoring stations in Tobago for 2014. Blue: Buccoo Reef, Green: Culloden and Red: Speyside.

The observed spatial variation in mean temperature and variability may influence the performance of satellite monitoring for each location. This is particularly of interest when applying $50 \mathrm{~km}$ data since all three sites are referenced to the same satellite pixel. 


\subsection{Comparison of in Situ Temperature with CRW $50 \mathrm{~km}$ and $5 \mathrm{~km}$ SST Data}

IST values for the three monitoring stations were compared with the CRW $50 \mathrm{~km}$ (twice-weekly) and $5 \mathrm{~km}$ (daily) SST. For the annual comparison with $50 \mathrm{~km}$ SST (Figure 4A-C), smaller magnitude biases found at Buccoo Reef and Culloden suggest there is more accurate representation of sea temperature at these reef sites than at Speyside. This is unsurprising given the pixel location to the northwest of Tobago, while Speyside is at the northeastern extent of Tobago facing the Atlantic Ocean (Figure 1). The corresponding RMSE values indicate there is a more consistent representation at Speyside and Buccoo Reef than at Culloden (Figure 4A-C).
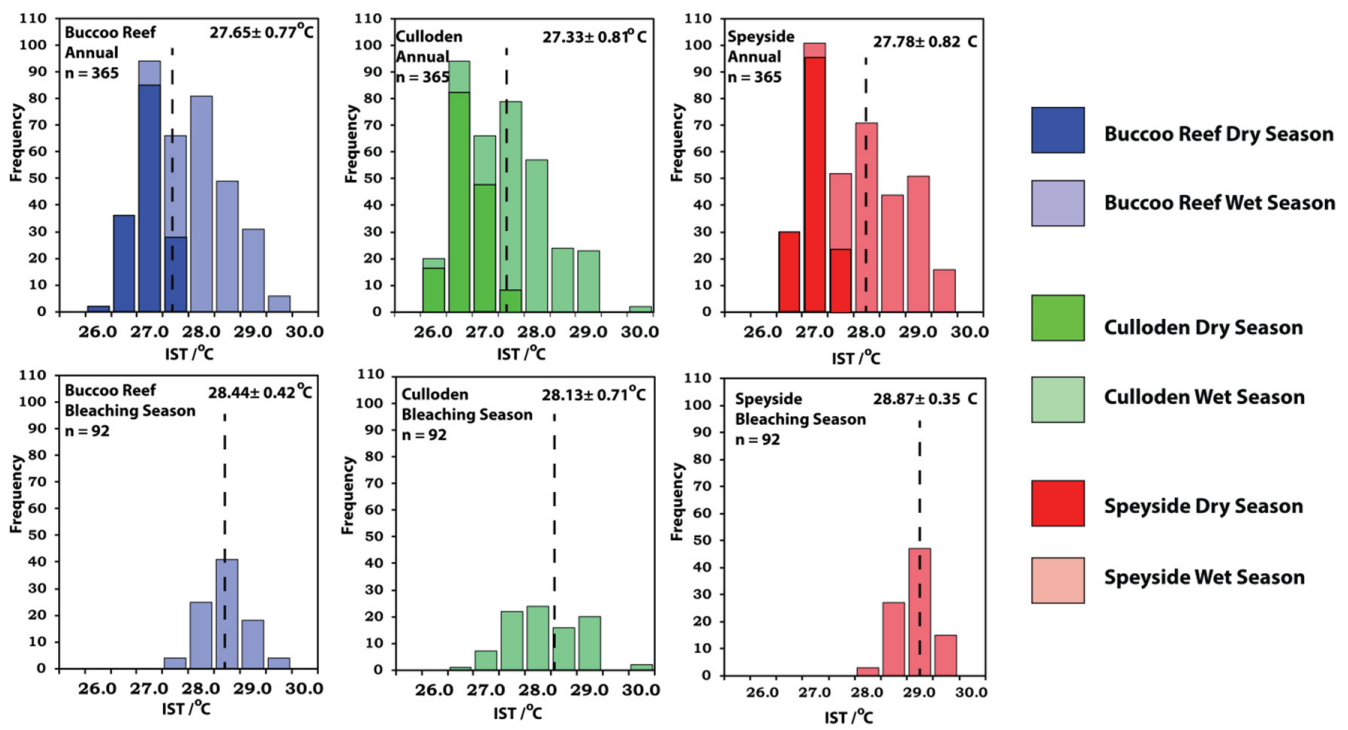

Figure 3. Histograms of in situ temperature (IST) recorded at three reefs off Tobago for annual (2014) and during the bleaching season (August to October, a subset of the wet season). Dashed line shows the temporal mean, also shown numerically with one standard deviation.
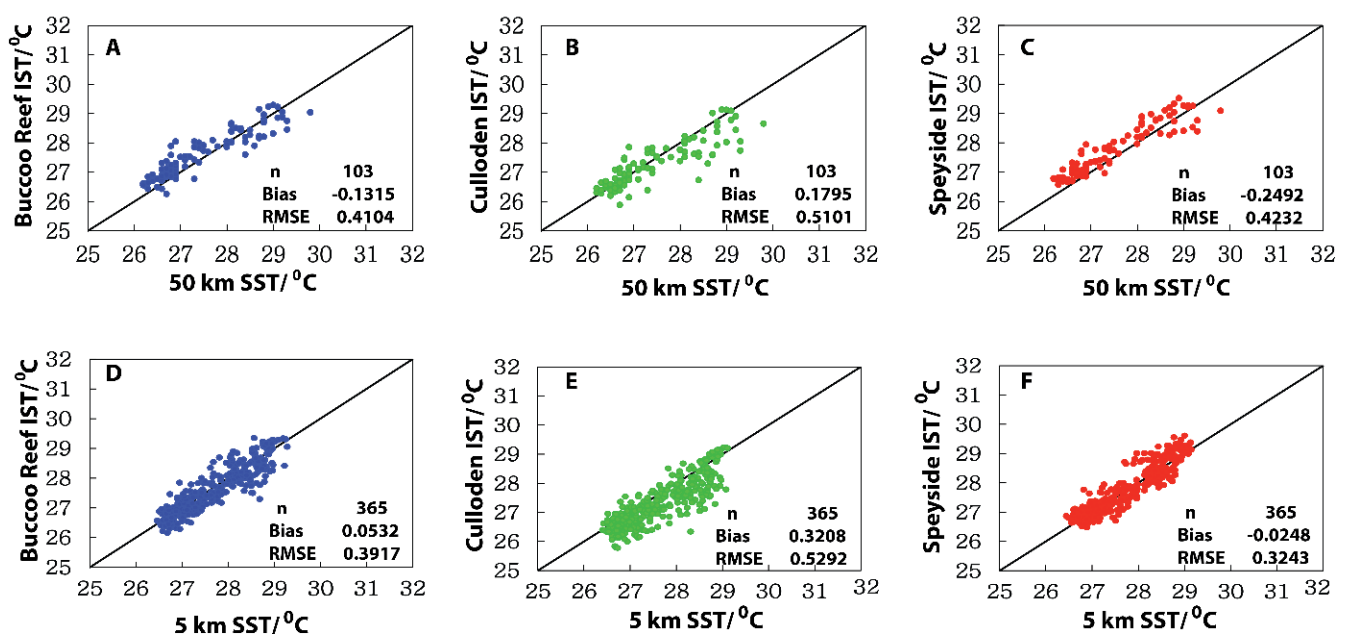

Figure 4. Comparison of $50 \mathrm{~km} \mathrm{SST} \mathrm{(A-C)} \mathrm{and} 5 \mathrm{~km} \mathrm{SST} \mathrm{(D-F)} \mathrm{with} \mathrm{in} \mathrm{situ} \mathrm{temperature} \mathrm{(IST)}$ measurements for 2014 at Buccoo Reef (A,D), Culloden (B,E) and Speyside (C,F), Tobago. The black line is the line of unity. Positive bias indicates SST greater than IST.

For the $5 \mathrm{~km} \mathrm{SST}$, the biases found in the year-round comparison indicated more accurate representation of IST at Speyside and Buccoo Reef than at Culloden. This might be related to the observed pixel coverage over water at Buccoo Reef and Speyside being substantially greater than 
at Culloden (Figure 1). The RMSE values showed less consistency between SST and IST at Culloden, compared with Buccoo Reef and Speyside (Figure 4D-F). The semi-enclosed nature of Culloden limits exposure to the northeast trade winds [43] resulting in less mixing of the water column, which can explain the higher bias and RMSE.

There is a notable improvement in the accuracy (bias) of the $5 \mathrm{~km} \mathrm{SST}$ at Speyside and Buccoo Reef compared with the $50 \mathrm{~km}$ SST. At Speyside, the negative bias for both $5 \mathrm{~km}$ and $50 \mathrm{~km} \mathrm{SST}$ indicates that IST is cooler than the SST produced at both spatial resolutions. In contrast, Culloden had a larger magnitude bias for the $5 \mathrm{~km} \mathrm{SST}$, which as explained above might be due to the limited pixel coverage or sheltered nature of this reef site. Improvements in the consistency with IST (given by RMSE) were generally observed for the $5 \mathrm{~km}$ annual RMSE over the $50 \mathrm{~km}$ values, as was seen with annual bias. At Culloden the RMSE value for the $5 \mathrm{~km}$ was similar to that produced for the $50 \mathrm{~km} \mathrm{SST}$; the consistency of representation of IST was the same for both satellite datasets.

Analyzing dry and wet seasons separately can reveal any seasonal changes in performance of the satellite SST. During the dry season, $50 \mathrm{~km} \mathrm{SST} \mathrm{at} \mathrm{Buccoo} \mathrm{Reef} \mathrm{and} \mathrm{Speyside} \mathrm{was} \mathrm{cooler} \mathrm{than} \mathrm{IST,}$ as indicated by the negative bias (Figure 5A,C). In contrast, dry season $50 \mathrm{~km} \mathrm{SST}$ at Culloden was warmer than the IST and with a smaller magnitude bias (Figure 5B). However, the consistency of the temperature difference (given by the RMSE) was very similar for all three sites.
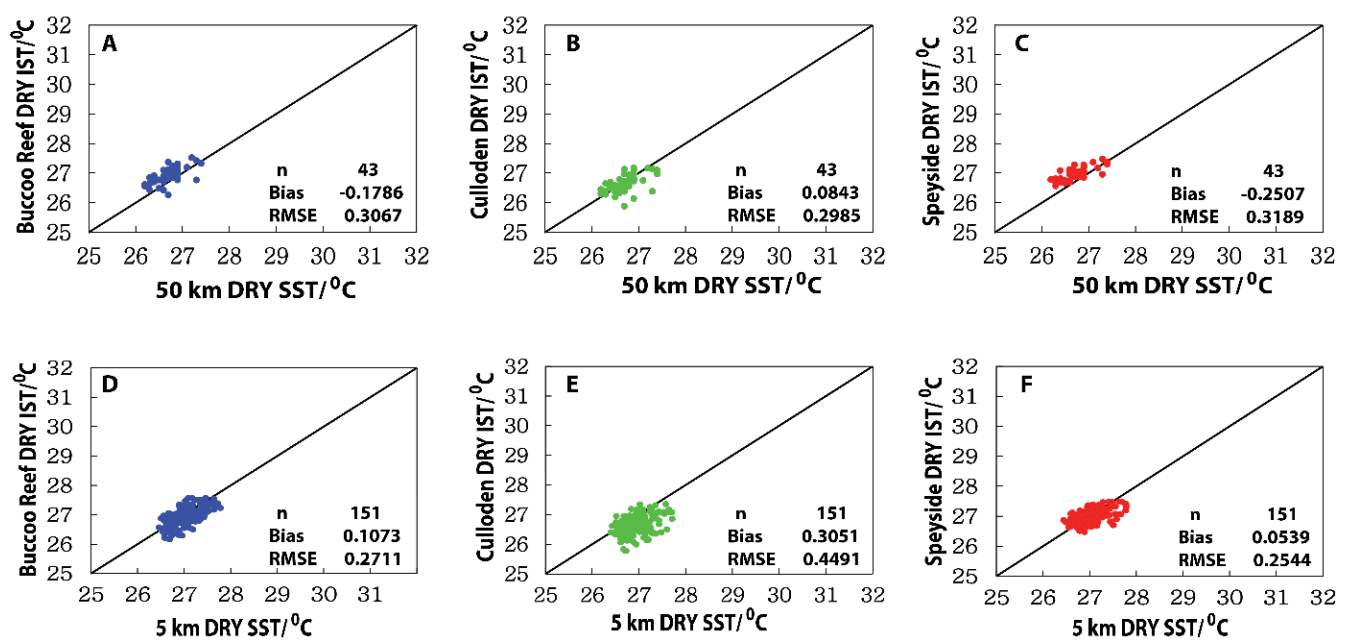

Figure 5. Comparison of $50 \mathrm{~km} \mathrm{SST} \mathrm{(A-C)} \mathrm{and} 5 \mathrm{~km} \mathrm{SST} \mathrm{(D-F)} \mathrm{with} \mathrm{in} \mathrm{situ} \mathrm{temperature} \mathrm{(IST)}$ measurements for the 2014 dry season at Buccoo Reef (A,D), Culloden (B,E) and Speyside (C,F), Tobago. The black line is the line of unity. Positive bias indicates SST greater than IST.

Dry season comparisons of $5 \mathrm{~km}$ SST showed the satellite values warmer than IST (positive bias) at all three reef sites. Consistency between $5 \mathrm{~km}$ SST and IST (i.e., the RMSE) was better at Buccoo Reef and Speyside, than at Culloden.

During the wet season the $50 \mathrm{~km}$ SST was cooler than IST at Buccoo Reef and Speyside but warmer than IST at Culloden (Figure 6A-C). Consistency between the $50 \mathrm{~km}$ SST and IST (i.e., RMSE) was better at Buccoo Reef and Speyside than at Culloden. The $5 \mathrm{~km}$ SST at Speyside was cooler than IST (negative bias, Figure 6F) and warmer than IST at Buccoo Reef and Culloden (Figure 6D,E);

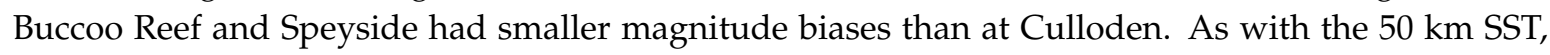
there is a more consistent representation of IST by the $5 \mathrm{~km}$ SST at Speyside and Buccoo Reef than at Culloden. Seasonal differences in the comparison of IST and SST may result from ITCZ movement over the southern Caribbean and related changes in cloud cover. Clouds obscure the ocean's surface, and thereby require gap filling of SST fields, which can reduce representation of in situ conditions $[44,45]$. 
Biases obtained using the $50 \mathrm{~km}$ SST dataset were generally larger during the wet season compared with the dry season, suggesting a reduced capacity of the $50 \mathrm{~km}$ SST to accurately represent the sea temperature during the bleaching period at all three reef sites. In contrast, biases obtained using the $5 \mathrm{~km}$ satellite dataset were smaller during the wet season than in the dry season, indicating higher accuracy in representing in situ temperatures during the wet season, which includes the bleaching period. However, for both $50 \mathrm{~km}$ and $5 \mathrm{~km}$ SST the RMSE was higher (i.e., consistency of the comparison was less) in the wet season than in the dry season, which might be due to increased water vapor in the atmosphere [43] and/or increased coastal influences such as river discharge.
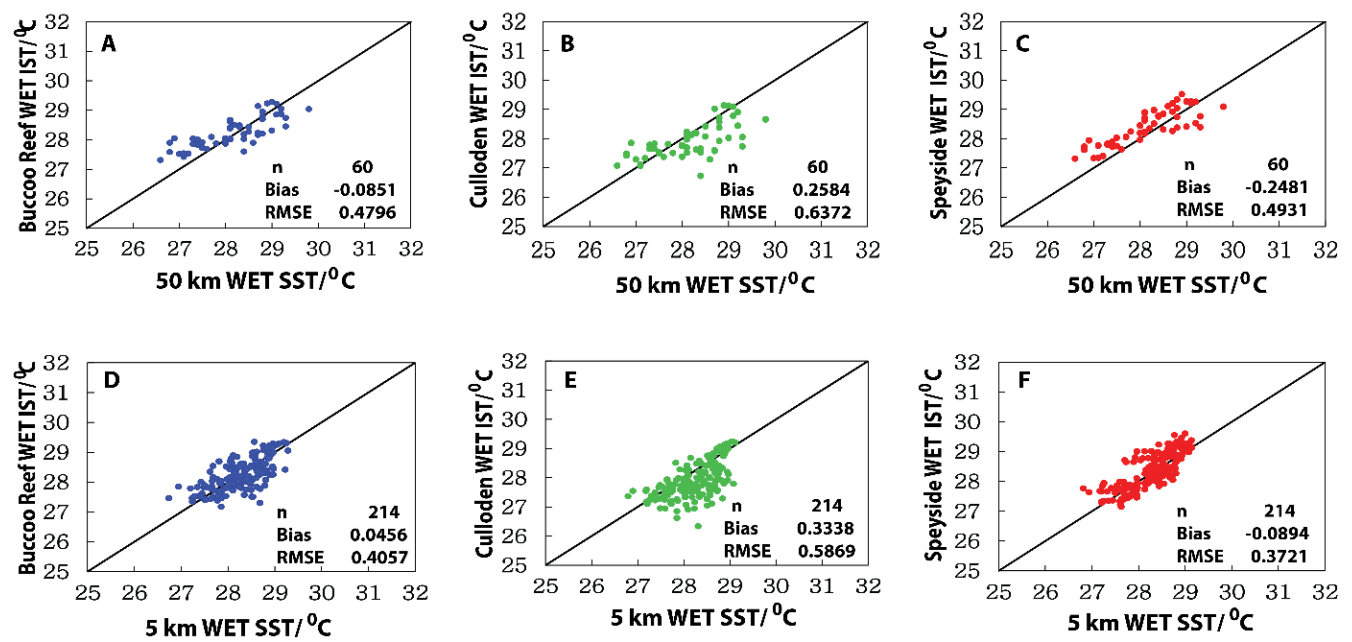

Figure 6. Comparison of $50 \mathrm{~km} \mathrm{SST} \mathrm{(A-C)} \mathrm{and} 5 \mathrm{~km} \mathrm{SST} \mathrm{(D-F)} \mathrm{with} \mathrm{in} \mathrm{situ} \mathrm{temperature} \mathrm{(IST)}$ measurements for the 2014 wet season at Buccoo Reef (A,D), Culloden (B,E) and Speyside (C,F), Tobago. The black line is the line of unity. Positive bias indicates SST greater than IST.

This coastal influence mostly affects Culloden, which recorded the highest RMSE values amongst the three reef sites during the wet season (Figure 5B,E). For Culloden there was also better representation of IST by the $50 \mathrm{~km} \mathrm{SST}$ than the $5 \mathrm{~km} \mathrm{SST}$, potentially due to the small coverage of water by the $5 \mathrm{~km}$ pixel or the sheltered nature of the site.

An overall comparison of the bias and RMSE between the $50 \mathrm{~km}$ and $5 \mathrm{~km}$ SST suggests that the $5 \mathrm{~km} \mathrm{SST} \mathrm{better} \mathrm{represents} \mathrm{in} \mathrm{situ} \mathrm{conditions} \mathrm{for} \mathrm{these} \mathrm{locations.} \mathrm{This} \mathrm{is} \mathrm{likely} \mathrm{to} \mathrm{result} \mathrm{from} \mathrm{greater}$ specificity of SST retrievals in the higher-resolution product, particularly at Buccoo Reef and Speyside (but note the limited representation by the $5 \mathrm{~km}$ SST pixel for Culloden). The bias and RMSE for the $50 \mathrm{~km} \mathrm{SST} \mathrm{for} \mathrm{Buccoo} \mathrm{Reef} \mathrm{were} \mathrm{generally} \mathrm{found} \mathrm{to} \mathrm{be} \mathrm{smaller} \mathrm{in} \mathrm{magnitude} \mathrm{than} \mathrm{the} \mathrm{corresponding}$ values for Culloden and Speyside. This is unsurprising given Buccoo Reef's proximity to the $50 \mathrm{~km}$ pixel. In contrast, Speyside is exposed to strong northeast trade winds year-round producing very different oceanographic conditions from Culloden or Buccoo Reef. Strong currents and choppy seas in shallow areas [26,46] provide good mixing of the water column. This may explain the higher magnitude bias, but with comparable consistency, between the IST and the $50 \mathrm{~km}$ SST datasets.

Use of temperature anomalies (i.e., the difference between the current temperature and a defined temperature baseline) can remove the effect of the bias between IST and SST. This is because the bias exists for both the temperature value and the baseline value, so subtraction of these cancels the bias terms. As such, an anomaly in the SST should represent well the IST anomaly provided there is good consistency (RMSE) between the datasets. Satellite thermal stress products (e.g., HS and DHW) are derived using anomalies and take advantage of the bias cancelling aspect to represent the temperature anomaly conditions on reefs using comparatively large-scale pixels. These thermal products measure the level of coral bleaching stress, which can be quantitatively assessed by comparing with observations made at reef sites. 


\subsection{Coral Bleaching Surveys and Thermal Stress Products for the Southern Caribbean}

Survey observations in 2013 made at Buccoo Reef, Culloden and Speyside showed bleaching at levels of $8 \%, 1 \%$ and $0 \%$, respectively (Figure 7). Montastrea annularis was the only recorded species to be bleached in Buccoo Reef, while M. faveolata and Porites astreoides were bleached at Culloden in 2013. The 2014 survey revealed less bleaching than in 2014 with 6\%, 0\% and 0\% of corals observed to be bleached at Buccoo Reef, Culloden and Speyside, respectively (Figure 7). P. porites was the only species to be partly bleached at Buccoo Reef. We note that the higher levels of bleaching at Buccoo Reef (compared with the other sites) may, in part, be attributed to increased susceptibility related to water quality and tourism activity.

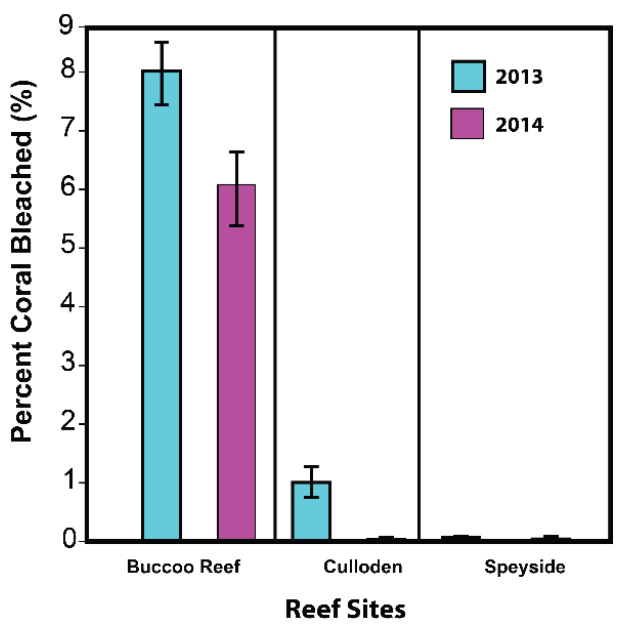

Figure 7. Percentage coral bleaching observed from the Reef Condition Monitoring Program (RECON) surveys conducted in September 2013 and September 2014 at Buccoo Reef, Culloden and Speyside.

The patterns of lower bleaching stress were consistent with lesser thermal stress in 2014 than in 2013 in both the $50 \mathrm{~km}$ and $5 \mathrm{~km}$ DHW products (Figures 8 and 9). In 2013, the $50 \mathrm{~km}$ SST produced a maximum DHW value of $4.55{ }^{\circ} \mathrm{C}$-weeks, while in 2014 it produced a maximum DHW value of $0.65{ }^{\circ} \mathrm{C}$-weeks (Figure 8). These values represent the predicted thermal stress at all three reef sites from a single $50 \mathrm{~km}$ pixel.

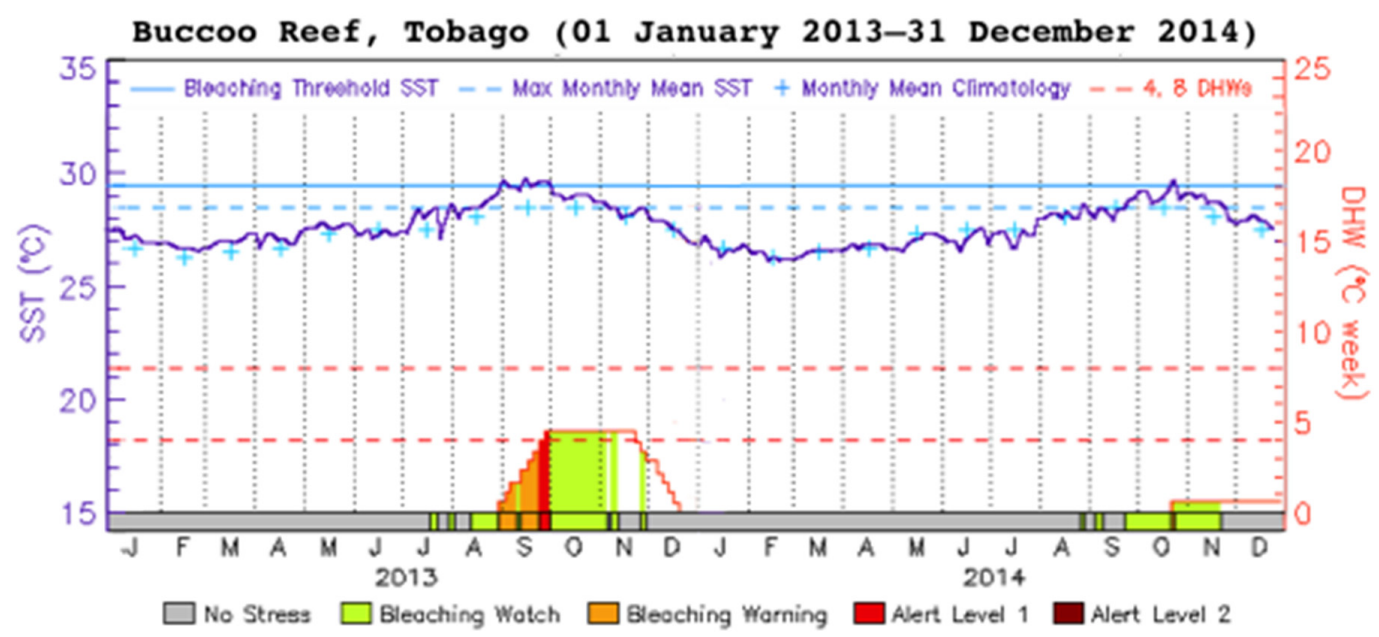

Figure 8. Twice-weekly $50 \mathrm{~km}$ sea surface temperature and Degree Heating Weeks (DHW) for 2013 and 2014. These products represent all three reefs sites: Buccoo Reef, Culloden and Speyside. 
In contrast, the $5 \mathrm{~km}$ DHW values that represent thermal stress at the three reef sites are from distinct pixels and therefore independent of each other (Figure 9). In 2013 the three maximum thermal stress values experienced at Buccoo Reef, Culloden and Speyside were $2.35^{\circ} \mathrm{C}$-weeks, $2.24^{\circ} \mathrm{C}$-weeks and $1.11^{\circ} \mathrm{C}$-weeks, respectively. In 2014, no DHWs were accumulated at Buccoo Reef, Culloden and Speyside (though temperature rose above the MMM producing maximum HotSpot values of $0.47^{\circ} \mathrm{C}$, $0.27^{\circ} \mathrm{C}$ and $0.31^{\circ} \mathrm{C}$, respectively; (Figure 9A-C). Buccoo Reef experienced the highest thermal stress in both years.

(A)

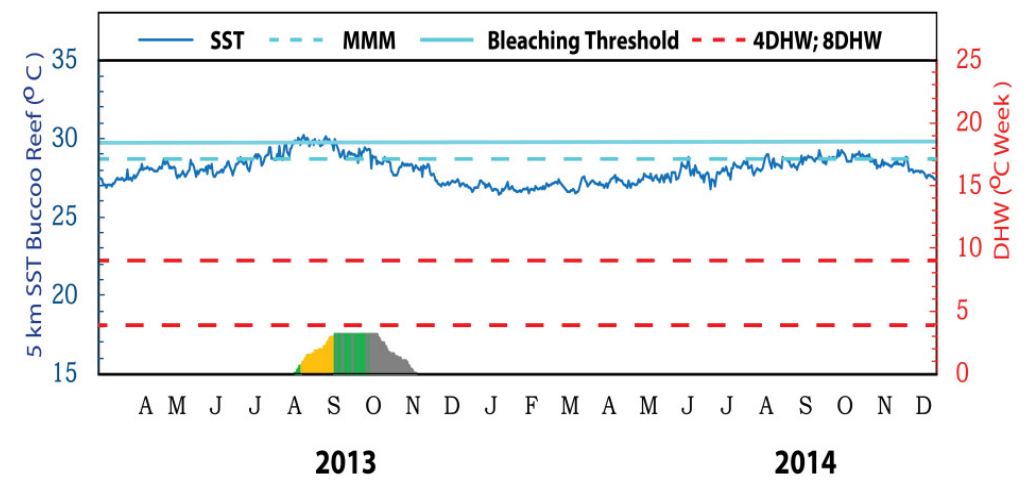

(B)

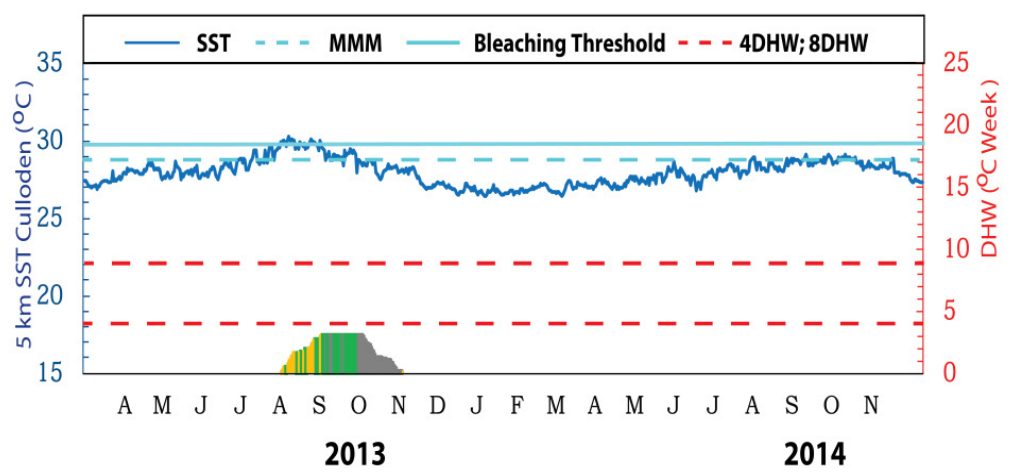

(C)

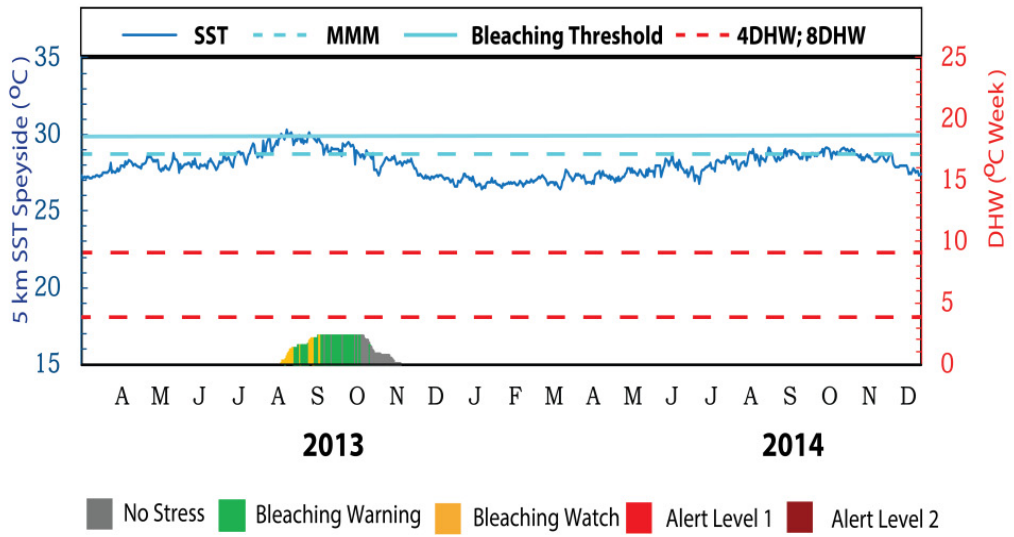

Figure 9. Daily $5 \mathrm{~km}$ sea surface temperature and Degree Heating Weeks (DHW) for 2013 and 2014. These products represent the three reefs sites in Tobago: (A) Buccoo Reef; (B) Culloden; and (C) Speyside.

Over the two bleaching seasons of 2013 and 2014, there was considerably less thermal stress on the corals as compared with previous mass bleaching events, such as occurred in 2005 and 2010 [32]. 
An Alert Level 1 was issued based on the $50 \mathrm{~km}$ DHW in 2013 (Figure 8). This DHW is above the reported value for significant bleaching ( $4{ }^{\circ} \mathrm{C}$-weeks [18]); while a small extent of bleaching was observed at Buccoo Reef (and minimally at Culloden), it appears that the $50 \mathrm{~km}$ product over-predicted the level of bleaching. The coarse resolution of the $50 \mathrm{~km}$ SST which only provides one DHW product to indicate the thermal stress experienced across these three sites highlights the limitation of the $50 \mathrm{~km}$ SST to detect localized conditions specific to each of the reef sites. This overestimation by the $50 \mathrm{~km}$ DHW was also observed in the northwestern Pacific and southeast Philippines [47]. In comparison, the $5 \mathrm{~km}$ DHW detected lower levels of thermal stress for 2013 at all sites (Figure 9), indicating that the CRW's $5 \mathrm{~km}$ thermal products provided improved DHW products at these three fringing reefs in the Southern Caribbean.

The differences in the environmental conditions of the coral reefs were best seen using the $5 \mathrm{~km}$ thermal products. Speyside experienced the highest annual and bleaching season mean SST but recorded the lowest DHW and the least bleaching. In contrast, Buccoo Reef experienced higher thermal stress and greater bleaching impact. As explained in the description of the study sites, Buccoo Reef is impacted by other factors that may make corals more vulnerable to thermal stress; e.g., tourism activities such as reef walking; nutrient enrichment from coastal run-off; and hurricane events [48,49].

\section{Conclusions}

Advancements of the NOAA CRW monitoring system through the implementation of near real-time, daily, global, $5 \mathrm{~km}$ satellite SST and thermal stress DSS products to monitor fringing coral at or near reef scales were highlighted in this study. The $5 \mathrm{~km}$ SST generally performed better than the $50 \mathrm{~km}$ in representing in situ temperature. The $5 \mathrm{~km}$ SST is more suitable to investigate coral reef thermal stress conditions for Tobago considering the overall smaller bias (i.e., greater accuracy) and smaller RMSE (i.e., greater consistency) when compared with the $50 \mathrm{~km}$ SST data. Comparing the $50 \mathrm{~km}$ and $5 \mathrm{~km}$ DHW for three fringing reef sites, the $5 \mathrm{~km}$ DHW product better matched the coral bleaching observations at these reef sites during the bleaching period. At Culloden, even though the biases in the comparison of the IST with the $5 \mathrm{~km}$ SST were relatively higher than those for the $50 \mathrm{~km}$ SST, the derived $5 \mathrm{~km}$ thermal stress products provided better agreement with bleaching survey data. This demonstrates the effectiveness of the use of SST anomalies in the DHW product. As noted in the $5 \mathrm{~km}$ product descriptions [23,41], it is important for managers to look for localized relationships like this so that they can understand how to best interpret the satellite products for their reefs.

Acknowledgments: The first author would like to express gratitude to the University of the West Indies (UWI), St. Augustine, in particular the Physics Department, for the funding support to initiate the in situ monitoring program with special mention to Shazaad Ali-Shah and Sadira Khan for their assistance on the fieldtrips. Sincere thanks to the Tobago House of Assembly (THA) for permission to conduct fieldwork at all reef sites, in particular Buccoo Reef, a Marine Protected Area (MPA). The contents in this manuscript are solely the opinions of the authors and do not constitute a statement of policy, decision or position on behalf of NOAA or the U.S. Government.

Author Contributions: Shaazia S. Mohammed planned and designed the study under the guidance of Scott F. Heron and Ricardo M. Clarke. Scott F. Heron extracted the satellite SST data. Shaazia S. Mohammed, Rajindra Mahabir, and Ricardo M. Clarke undertook the fieldwork. Rajindra Mahabir identified the coral species from the RECON survey. Shaazia S. Mohammed conducted the analysis of data. Shaazia S. Mohammed, Scott F. Heron, and Ricardo M. Clarke wrote the paper with comments, revisions and suggestions from all authors.

Conflicts of Interest: The authors declare no conflict of interest.

\section{References}

1. Fitt, W.K.; Brown, B.E.; Warner, M.E.; Dunne, R.P. Coral bleaching: Interpretation of thermal tolerance limits and thermal thresholds in tropical corals. Coral Reefs 2001, 20, 51-65. [CrossRef]

2. Guest, J.R.; Baird, A.H.; Maynard, J.A.; Muttaquin, E.; Edwards, J.A.; Campbell, J.A.; Yewdall, K.; Affendi, Y.A.; Chou, L.M. Contrasting patterns of coral bleaching susceptibility in 2010 suggest an adaptive response to thermal stress. PLoS ONE 2010, 7, 1-8. [CrossRef] [PubMed] 
3. Graham, N.A.J.; Wilson, K.A.; Jennings, S.; Polunin, N.V.C.; Robinson, J.; Bijoux, J.P.; Daw, T.M. Lag effects in the impacts of mass coral bleaching on coral reef fish, fisheries and ecosystems. Conserv. Biol. 2006. [CrossRef] [PubMed]

4. Pratchett, M.S.; Hoey, A.S.; Wilson, S.K.; Messmer, V.; Grahan, N.A.J. Changes in biodiversity and functioning of reef fish assemblages following coral bleaching and coral loss. Diversity 2011, 3, 424-452. [CrossRef]

5. Mallela, J.; Parkinson, R.; Day, O. An Assessment of Coral Reefs in Tobago. Caribb. J. Sci. 2010, 46, 83-87. Available online: https://scholar.google.com/scholar?q=An+assessment+of+coral+reefs+in+Tobago (accessed on 3 June 2015).

6. Doshi, A.; Pascoe, S.; Thébaud, O.; Thomas, C.R.; Setiashi, N.; Hong, J.T.C.; True, J.; Schuttenberg, H.Z.; Heron, S.F. Lost of economic value for coral bleaching in S.E. Asia. In Proceedings of the 12th International Coral Reef Symposium, Cairns, QLD, Australia, 9-13 July 2012.

7. Liu, G.; Eakin, M.C.; Rauenzahn, J.L.; Christensen, T.R.L.; Heron, S.F.; Li, J.; Skirving, W.; Strong, A.E.; Burgess, T. NOAA coral reef watch's decision support system for coral reef management. In Proceedings of the 12th International Coral Reef Symposium, Cairns, QLD, Australia, 9-13 July 2012.

8. McClanahan, T.R.; Ateweberhan, M.; Muhando, C.A.; Maina, J.; Mohammed, S. Effects of climate and seawater temperature variation on coral bleaching and mortality. Ecol. Monogr. 2007, 77, 503-525. [CrossRef]

9. McClanahan, T.R.; Ateweberhan, M.; Sebastián, C.R.; Graham, N.A.J.; Wilson, S.K.; Bruggeman, J.H.; Guillaume, M.M.M. Predictability of coral bleaching from a synoptic satellite and in situ temperature observations. Coral Reefs 2007, 26, 695-701. [CrossRef]

10. Andréfouët, S.; Riegl, B. Remote sensing: A key tool for interdisciplinary assessment of coral reef processes. Coral Reefs 2004, 23, 1-4. [CrossRef]

11. Smale, D.A.; Wernberg, T. Satellite-derived SST data as a proxy for water temperature in nearshore benthic ecology. Mar. Ecol. Prog. Ser. 2009, 387, 27-39. [CrossRef]

12. Berkelmans, R.; Déath, G.; Kininmonth, S.; Skirving, W.J. A comparison of the 1998 and 2002 coral bleaching events on the Great Barrier Reef: Spatial correlation, patterns and predictions. Coral Reefs 2004, 23, 78-83. [CrossRef]

13. Donner, S.D.; Skirving, W.J.; Little, C.M.; Oppenheimer, M.; Hoegh-Guldberg, O. Global assessment of coral bleaching and required rates of adaptation under climate change. Glob. Chang. Biol. 2005, 11, 2251-2265. [CrossRef]

14. Wilkinson, C. Executive summary. In Status of Coral Reefs of the World: 2008; Global Coral Reef Monitoring Network: Townsville, QLD, Austalia, 2008; pp. 5-19.

15. Strong, A.E.; Liu, G.; Meyer, J.; Hendee, J.C.; Sasko, D. Coral Reef Watch 2002. Bull. Mar. Sci. 2004, 75, 259-268.

16. Skirving, W.J.; String, A.E.; Liu, G.; Liu, C.; Arzayus, F.; Sapper, J.; Bayler, E. Extreme events and perturbations of coastal ecosystems. In Remote Sensing of Aquatic Coastal Ecosystem Processes, 1st ed.; Richardson, L.L., LeDrew, E.F., Eds.; Springer: Dordrecht, The Netherlands, 2006; pp. 11-23.

17. Heron, S.F.; Heron, M.L.; Pichel, W.G. Thermal and radar. In Coral Reef Remote Sensing: A Guide for Mapping, Monitoring and Management, 1st ed.; Goodman, J.A., Purkis, S.J., Phinn, S.R., Eds.; Springer: New York, NY, USA, 2013; pp. 285-312.

18. Liu, G.; Strong, A.E.; Skirving, W. Remote sensing of sea surface temperature during 2002 Barrier Reef Coral Bleaching. Eos Trans. Am. Geophys. Union 2003, 84, 137-144. Available online: http:/ / onlinelibrary.wiley.com/doi/10.1029/2003EO150001/pdf (accessed on 25 June 2015). [CrossRef]

19. Eakin, C.M.; Lough, J.M.; Heron, S.F. Climate variability and change: Monitoring data and evidence for increased coral bleaching stress. In Coral Bleaching, 1st ed.; van Oppen, M.J.H., Lough, J.M., Eds.; Springer: Berlin, Germany, 2005; pp. 41-67.

20. Strong, A.E.; Liu, G.; Kimura, T.; Yamano, H.; Tschuiya, M.; Kakuma, S.; vanWoesik, R. Detecting and monitoring 2001 coral reef bleaching events in Ryuku Islands, Japan using satellite bleaching hotspot remote sensing technique. In Proceedings of the Geoscience and Remote Sensing Symposium, Toronto, ON, Canada, 24-28 June 2002. 
21. Eakin, M.C.; Morgan, J.A.; Heron, S.F.; Smith, T.B.; Liu, G.; Alverez-Filip, L.; Baca, B.; Bartels, E.; Bastida, C.; Bouchon, C.; et al. Caribbean Corals in Crisis: Record Thermal Stress, Bleaching, and Mortality in 2005. PLoS ONE 2010, 5, 1-9. [CrossRef] [PubMed]

22. Mumby, P.J.; Skirving, W.; Strong, A.E.; Hardy, J.T.; LeDrew, E.F.; Hochberg, E.J.; Stumpf, R.P.; David, L.T. Remote Sensing of coral reefs and their physical environment. Mar. Pollut. Bull. 2004, 48, 219-228. [CrossRef] [PubMed]

23. Liu, G.; Eakin, M.C.; Muller-Karger, F.E.; Vega-Rodrigues, M.; Guild, L.S.; de La Cour, J.L.; Geiger, E.F.; Skriving, W.J.; Burgess, T.F.R.; et al. Reef-Scale thermal stress monitoring of coral ecosystems: New 5-km global products from NOAA coral reef watch. Remote Sens. 2014, 6, 11579-11606. [CrossRef]

24. Liu, G.; Heron, S.F.; Eakin, M.C.; Rauenzahn, J.L.; Geiger, E.F.; Skirving, W.J.; Burgess, T.F.R.; Strong, A.E. NOAA coral reef watch next-generation $5 \mathrm{~km}$ satellite coral bleaching thermal stress monitoring. News Int. Soc. Reef Stud. 2014, 29, 27-29.

25. NOAA Coral Reef Watch Product Description of Daily Global $5 \mathrm{~km}$ Satellite Coral Bleaching Thermal Stress Monitoring Products (Version 1). Available online: http://coralreefwatch.noaa.gov/satellite/ bleaching5km/description5km_v1.php (accessed on 25 June 2015).

26. Laydoo, R.S. The Fore-Reef Slopes of the Buccoo Reef Complex, Tobago, 1st ed.; Institute of Marine Affairs: Chaguaramas, Trinidad and Tobago, 1985; pp. 2-4.

27. Peterson, L.C.; Haug, G.H. Variability in the mean latitude of the Atlantic Intertropical Convergence Zone as recorded by riverine input of sediment to the Cariaco Basin. Paleogeogr. Paleoclimatol. Paleoecol. 2006, 243, 97-113. [CrossRef]

28. Warne, A.G.; Meade, R.H.; White, W.A.; Guevara, E.H.; Gibeaut, J.; Smyth, R.C.; Aslan, A.; Tremblay, T. Regional controls on geomorphology, hydrology, and ecosystem integrity in the Orinoco Delta, Venezuela. Geomorphology 2002, 44, 273-307. [CrossRef]

29. Muller-Karger, F.E.; Castro, R.A. Mesoscale processes affecting phytoplankton abundance in the southern Caribbean Sea. Cont. Shelf Res. 1994, 14, 199-221. [CrossRef]

30. Beharry, S.L.; Clarke, R.M.; Kumarsingh, K. Precipitation trends using in-situ gridded datasets. Theor. Appl. Climatol. 2014, 115, 599-607. [CrossRef]

31. Burke, L.; Maidens, J. Reefs at Risk in the Caribbean, 1st ed.; World Resource Institute: Washington, DC, USA, 2004; pp. 5-8.

32. Alemu I, J.B.; Clement, Y. Mass coral bleaching in 2010 in the southern Caribbean. PLoS ONE 2014, 9, 1-8. [CrossRef]

33. McWilliams, J.P.; Côte, I.M.; Gill, J.A.; Sutherland, W.J.; Watkinson, A.R. Accelerating impacts of temperature-induced coral bleaching in the Caribbean. Ecology 2005, 86, 2055-2060. [CrossRef]

34. Liu, G.; Rauenzahn, J.L.; Heron, S.F.; Eakin, C.M.; Skirving, W.; Christensen, T.R.L.; Strong, A.E.; Li, J. NOAA Coral Reef Watch $50 \mathrm{~km}$ Satellite Sea Surface Temperature-Based Decision Support System for Coral Bleaching Management; NOAA: Washington, DC, USA, 2013; p. 27.

35. Liu, G.; Heron, S.F.; Eakin, C.M.; Rauenzahn, J.L.; Geiger, E.F.; Skirving, W.J.; Burgess, T.F.R.; Strong, A.E. NOAA coral reef watch's next-generation $5 \mathrm{~km}$ satellite coral bleaching thermal stress monitoring. Reef Encount. 2004, 2, 27-29.

36. HOBO Water Temperature Pro v2 Data Logger-U22-001. Available online: http://www.onsetcomp.com/ products/data-loggers/u22-001?qt-product-tabs=1\#qt-product-tabs (accessed on 13 July 2015).

37. Weeks, S.J.; Berkelmans, R.; Heron, S.F. Thermal applications. In Coral Reef Remote Sensing: A Guide for Mapping, Monitoring and Management, 1st ed.; Goodman, J.A., Purkis, S.J., Phinn, S.R., Eds.; Springer: London, UK, 2013; pp. 313-339.

38. Parker, B.A.; Christensen, T.R.; Heron, S.F.; Morgan, J.A.; Eakin, C.M. A Classroom activity using satellite sea surface temperatures to predict coral bleaching. Oceanography 2009, 2, 252-257. [CrossRef]

39. Guo, P.; Bo, Y. Validation of AVHRR/MODIS/AMSR-E satellite SST products in the West Tropical Pacific. In Proceedings of the Geoscience and Remote Sensing Symposium, Boston, MA, USA, 6-11 July 2008.

40. Heron, S.F.; Liu, G.; Eakin, M.C.; Skirving, W.J.; Muller-Karger, F.E.; Vega-Rodriguez, M.; de La Cour, J.L.; Burgess, T.F.R.; Strong, A.E.; Geiger, E.F. Climatology Development for NOAA Coral Reef Watch's 5-km Product Suite; NOAA: Washington, DC, USA, 2014; pp. 1-14. 
41. Heron, S.F.; Johnston, L.; Liu, G.; Geiger, E.F.; Maynard, J.A.; de La Cour, J.L.; Johnson, S.; Okano, R.; Benavente, D.; Burgess, T.F.R.; et al. Monitoring coral bleaching using high-resolution thermal stress satellite products. Remote Sens. 2015, in press.

42. Hill, J.; Wilkinson, C. Methods for Ecological Monitoring of Coral Reefs, Version 1, A Resource for Managers; Australian Institute of Marine Science: Townsville, QLD, Australia, 2004; p. 117. Available online: www.icriforum.org/sites/default/files/GCRMN_Ecological_monitoring.pdf (accessed on 1 July 2013).

43. Laydoo, R.S. Introduction. The Reefs at Culloden Bay, Tobago, 1st ed.; Institute of Marine Affairs: Chaguaramas, Trinidad and Tobago, 1985; pp. 1-3.

44. Ricciardulli, L.; Wentz, L.J. Uncertainties in sea surface temperature retrievals from space: Comparison of microwave and infrared observations from TRMM. J. Geophys. Res. 2004, 109, 1-16. [CrossRef]

45. Wick, G.A.; Bates, J.J.; Scott, D.J. Satellite and skin layer effects on the accuracy of sea surface temperature measurements from the GOES satellite. J. Atmos. Ocean. Technol. 2002, 19, 1834-1848. [CrossRef]

46. Laydoo, R.S. Introduction. The Coral Reefs at Speyside, Tobago, 1st ed.; Institute of Marine Affairs: Chaguaramas, Trinidad and Tobago, 1985; pp. 2-4.

47. Heron, S.F.; Liu, G.; Rauenzahn, J.L.; Christensen, T.R.L.; Skirving, W.J.; Burgess, T.F.R.; Eakin, C.M.; Morgan, J.A. Improvements to the continuity of operational global thermal stress monitoring for coral bleaching. J. Oper. Oceanogr. 2014, 7, 3-11. [CrossRef]

48. Lapointe, B.E.; Langton, R.; Bedford, B.J.; Potts, A.C.; Day, O.; Hu, C. Land-Based nutrient enrichment of the Buccoo Reef complex and fringing coral reefs of Tobago, West Indies. Mar. Pollut. Bull. 2010. [CrossRef] [PubMed]

49. Mallela, J.; Crabbe, M.J.C. Hurricanes and coral bleaching linked to changes in coral recruitment in Tobago. Mar. Environ. Res. 2009, 68, 158-162. [CrossRef] [PubMed]

(C) 2015 by the authors; licensee MDPI, Basel, Switzerland. This article is an open access article distributed under the terms and conditions of the Creative Commons by Attribution (CC-BY) license (http:/ / creativecommons.org/licenses/by/4.0/). 